\title{
BUDGET DEFICITS AND INFLATION: THE ROLES OF CENTRAL BANK INDEPENDENCE AND FINANCIAL MARKET DEVELOPMENT
}

\author{
BILIN NEYAPTI*
}

\begin{abstract}
This article investigates the relationship between budget deficits and inflation with the view that the nature of this relationship depends on the characteristics of monetary and financial institutions. The main hypothesis is that budget deficits are especially inflationary when both the central bank is not independent and the financial market is not developed enough to contain inflationary expectations. The empirical analysis using a panel data that comprises 54 developed and less developed countries, with one to two decades of observations for each, supports this hypothesis. The findings are also robust to subsets of the sample. (JEL E58, H62)
\end{abstract}

\section{INTRODUCTION}

If a government's spending exceeds its revenue, the resulting deficits have to be financed either through borrowing or issuing money. However, borrowing is limited by the public's capacity or willingness to hold additional government debt, and monetary expansion leads to inflation. Although inflation is socially inefficient and politically unpopular for many reasons ${ }^{1}$, it has been either recurrent or persistent

\footnotetext{
*This is a revision of the paper presented at the Western Economic Association International 74th annual conference, San Diego, July 8, 1999. The author is grateful for the comments and suggestions of the participants at this conference, at the 1998 METU Conference in International Economics, and at the 1998 Canadian Economic Association Meetings, in addition of the seminar participants at Bilkent University, Boğaziçi University, and at the Central Bank of the Turkish Republic during 1997 and 1998, as well as of the anonymous referees. The authors is also deeply indebted to Mancur Olson for his invaluable comments towards the completion of doctoral dissertation and beyond. This paper was a significant part of the author's doctoral dissertation.

Neyapti: Assistant Professor of Economics, Bilkent

University, Department of Economics, 06800 Bilkent,

Ankara, Turkey. Phone (90 312) 290 2030, Fax $(90$

312) 266 5140, E-mail neyapti@bilkent.edu.tr
}

1. Inflation may deteriorate income distribution, generates uncertainty in economic decisions, may lower investment and output, and therefore may lead to higher budget deficits due to a smaller tax base. Inflation may also increase budget deficits by increasing the debt service, by encouraging tax evasion, or by means of delays in tax collection, generally referred to as the Tanzi effect (Tanzi, 1997). Moreover, inflation lowers the value of money balances, leading people to hold lower real balances. Hence, above some inflation rate, real revenues from money creation start to fall as inflation continues to rise (see, for example, Bailey, 1956). in many economies. Although policy mistakes seem to provide an explanation for this, it is inadequate because learning from past mistakes would prevent inflation from being either recurrent or persistent over long periods. Revenues from inflationary monetary expansion that benefit governments and special interest groups, on the other hand, help explain why inflation is recurrent or persistent.

This study takes into account such special group incentives for inflation in investigating the relationship between budget deficits and inflation. This article argues that besides the social or political concerns of governments, a large measure of budget deficits results from organized interest groups that pressure the government to spend beyond its revenues. Especially in less developed countries, where both the financial market and tax collection mechanisms are not sufficiently developed to provide the government with the resources it needs, a major way to finance these deficits is money creation. Although money creation generates seignorage revenues, it also leads to inflation tax. In contrast with other forms of taxation, inflation tax is easy to implement, and its costs may be hidden temporarily, even

\section{ABBREVIATIONS}

FMD: Financial Market Development CBI: Central Bank Independence GMM: Generalized Methods of Moments GDP: Gross Domestic Product

CIM: Contract Intensive Money OLS: Ordinary Least Squares 
though its long-term costs are widely dispersed. It is therefore socially efficient to build institutions that serve long-term price stability.

The main hypothesis of this article is that budget deficits lead to inflation particularly when the financial market is not developed and the central bank is not independent. The author hypothesizes that the degrees of both financial market development and central bank independence affect not only the degree of monetary accommodation of budget deficits in a given period but also the expectations about future monetary accommodation of budget deficits.

Financial market development results from both market forces and an institutional framework that facilitates efficient allocation of financial resources. Developed financial markets allocate funds to maximize profits and typically generate funds through their own operations, rather than through central bank lending. Therefore, they offer non- or less inflationary means to finance budget deficits. In addition, financial intermediaries are net lenders because they usually engage in long-term lending at fixed rates and short-term borrowing at variable market rates. Unanticipated inflation thus threatens the well-being of at least a part of the financial system. A financial sector that operates with a profit motive and relies on its own resources would therefore tend to advocate anti-inflationary policies. Recent studies (for example, Goodman, 1991; Posen, 1994, 1995; Maxfield, 1994; Al-Marhubi and Willett, 1995) argue that politically powerful interest group incentives play an essential role in building institutions, such as an independent central bank, to credibly commit to price stability. Moreover, both Goodman (1991) and Posen (1994, 1995) argue that the financial sector, along with the support of the nonfinancial sector, is most likely to generate such powerful anti-inflation lobbies that support an independent central bank, which targets price stability.

Central bank independence is generally viewed as an institutional device for committing to price stability (see, for example, Rogoff, 1985; Alesina and Tabellini, 1987; Cukierman, 1992). It may, however, result due to either a government with long-term expected tenure that therefore cares for the long-term costs of inflation or governments that have short tenure and would like to limit their successors' control over monetary policy (see Goodman, 1991).
Whatever the circumstances for establishing an independent central bank may be, the maintenance of its independence requires supporting societal preferences. An independent central bank facilitates the emergence of anti-inflation lobbies by way of imposing hard budget constraints, which force financial intermediaries to internalize the costs of risky lending and thus allocate credits efficiently. Efficient allocation of resources, in turn, drive inefficient enterprises out of the market, helping reduce both budget deficits and thereby the pressures for monetary expansion. Thus, financial market development (FMD) allows for price-stability and provides a favorable environment for central bank independence (CBI). The coexistence of FMD and CBI therefore indicates a symbiotic relationship.

The basic motivation for this study is the lack of adequate analysis of the relationship between budget deficits and inflation with an account for the institutional variation across countries. Although there is vast empirical evidence on the negative relationship between central bank independence and price stability (see, for example, Parkin and Bade, 1978; Grilli et al., 1991; Alesina and Summers, 1993; Cukierman et al. 1992, 2002; Neyapti, 2001), empirical studies have not analyzed the relationship between budgetdeficits and inflationwhile also accounting for the characteristics of monetary and financial institutions across the sample. ${ }^{2}$ Existing empirical studies on the relationship between budget deficits and inflation generally use time-series analysis and mostly concentrate on developed countries. ${ }^{3}$ Besides, the existing studies are inconclusive about the nature of this relationship not only because their findings, either across countries or over time, range from no significant relationship to a positive or even to a negative one but also because they do not attempt to systematically address these differences.

2. An exception is Burdekin and Wohar (1990), who perform a time-series study of eight developed countries. They find that budget deficits are not inflationary. Moreover, in countries with independent central banks monetary accommodation of deficits is lower and money growth is less inflationary.

3. Some examples to such studies are Dwyer (1982), Giannaros and Kolluri (1985), Ahking and Miller (1986), and Darrat (1985). Studies on less developed countries, on the other hand, tend to show a positive causal effect of budget deficits on inflation; see, for example, Choudary and Parai (1991) and Metin (1998). 
Contrary to a misconception that appears in some of these empirical studies, the lack of a contemporaneous relationship between inflation and budget deficits does not rule out their close association. Indeed, theoretical studies on the relationship between budget deficits and inflation (see, for example, Sargent and Wallace, 1985) point out that if budget deficits are either not financed or not expected in the future to be financed through additional money issue, prices do not rise. These studies also point out, however, that if government debt becomes unsustainable, budget deficits eventually leads to inflation, even though they are not currently financed through monetary expansion.

How budget deficits are financed can thus explain why they might not be necessarily and strongly linked with inflation and-even though they might be strongly linked-why this linkage might not be contemporaneous. For instance, when high inflation creates an incentive for the government to delay its interest payments, there may appear to be no contemporaneous correlation between budget deficits, measured on cash rather than accrual basis, and inflation. In addition, because quasifiscal deficits are both difficult to measure and are therefore often not accounted for in budget deficits, their existence may temporarily conceal the linkage between budget deficits and inflation. To create an impression of good economic performance, governments with a short horizon may therefore lower budgetary spending and increase extrabudgetary spending. Moreover, a downward adjustment in budget deficits to eliminate inflationary pressures, usually pursuant to very high inflation rates, may also conceal the positive linkage between inflation and budget deficits when investigated on a contemporaneous level.

In view of all these factors that are likely to conceal or eliminate the contemporaneous relation between budget deficits and inflation, this article analyzes the lagged relationship between budget deficits and inflation. To do this, the author uses a panel of time-series and cross-sections that include both developed and less developed countries also explicitly accounts for the institutional variation across countries.

To this end, the author employs several measures of both CBI and FMD. Two measures of CBI are provided by Cukierman et al. (1992): (1) legal indices of $\mathrm{CBI}^{4}$ and (2) the turnover rates of central bank governors. FMD is measured by (1) the share of banking sector credit to the private sector in the total banking sector credit; (2) financial deepening; and (3) the noncurrency component of broad money (referred to as contract-intensive money in Clague at al., 1995). Although neither of these measures is the ideal measure of either CBI or FMD, the author tries to overcome each of their potential deficiencies by using them jointly in the empirical analysis.

To test the hypothesis that FMD and CBI affect the extent to which budget deficits are inflationary, a sample is used that covers 54 developed and less developed countries, each with time-series that cover 10-20 years. Hence, the panel is unbalanced. The use of a panel data set enables one to capture the variation in the institutional characteristics and thus their effect on the relationship between budget deficits and inflation. Given the dynamic nature of the equations, however, the possibility of countryspecific fixed effects presents potential estimation problems (see, for example, Balestra and Nerlove, 1966; Nickell, 1981). To overcome these estimation problems, we use an instrumental technique, developed by Arellano and Bond (1988) that utilizes generalized methods of moments (GMM) and also accommodates the use of an unbalanced panel data.

The results of the empirical analysis suggest that the positive effect of budget deficits on inflation is especially strong when the degrees of CBI and FMD are low. Though several measures of both CBI and FMD are used, these results are obtained especially when $\mathrm{CBI}$ is proxied by the rate of turnover of central bank presidents and when FMD is proxied both by banking sector credit to the private sector credit in ratio to total banking sector credit and by contract intensive money. The findings are also robust to samples that exclude high inflation rates, except that in those samples one observes significant effects of FMD in case it is measured by financial deepening, rather than by banking sector credit to the private sector credit in ratio to total banking sector credit.

4. Banaian et al. (1998) caution investigate the potential problems contained in the legal CBI index of Cukierman et al. (1992). Nevertheless this index is used here as one proxy of $\mathrm{CBI}$ - along with the alternative measure of CBI developed by the same authors-for it is the most comprehensive coding of legal CBI generated so far for a large set of countries. 
The remainder of this article is organized as follows. Section II presents an analytical model of the intertemporal relationship between deficits and inflation. Section III presents the data, observations, and empirical analysis of the relationship between budget deficits and inflation in view of the characteristics of monetary and financial institutions. Section IV concludes.

\section{THE MODEL}

This section provides an analytical derivation of the intertemporal linkage between budget deficits and inflation. To do that, the author first establishes the link between inflation and money growth via money market equilibrium condition. Next, using this relationship and an intertemporal budget constraint and assuming that the degree of monetary accommodation that satisfies the government's budget constraint depends on both CBI and FMD, the author expresses inflation as a function of the present value of budget deficits in interaction with the degrees of CBI and FMD.

Following Sargent (1986), the money market equilibrium condition is expressed using a linear version of Cagan's (1956) formulation of money demand:

$$
M_{t} / P_{t}=\alpha-\beta \pi_{t+1}^{e}
$$

where $M$ stands for money and $P$ for the price level. $\alpha$ stands for both real income and real interest rates, both of which, for simplicity, are assumed to be constant and to satisfy the

$$
\pi_{t+1}^{e}=E\left(\pi_{t+1} \mid I_{t}\right)
$$

condition: $\alpha>\beta>0 .^{5}$ The author further assumes that inflationary expectations, $\pi_{t+1}^{e}$, are formed rationally: where $\pi_{t+1}^{e}=P_{t+1} / P_{t}$ and $I_{t}$ is the information set available at time $t$. Equation (1) shows that in equilibrium, real money supply is equal to real money demand, where the latter is a negative function of the expected inflation rate. Hence, the higher the expectation about the rate of inflation in period

5. This assumption is relaxed later in the empirical analysis by controlling for real growth. $t+1$, the smaller the demand for real money balances at time $t$.

$$
P_{t}=(B / \alpha) P_{t+1}^{e}+(1 / \alpha) M_{t}
$$

From equation (1), one obtains an expectational difference equation for the price level. After continuous forward substitutions for the expected price level and first differencing the resulting expression, one obtains

$$
\Delta P_{t}=(1 / \alpha) \sum_{i=0}^{\infty}(B / \alpha)^{i} E\left(\Delta M_{t+i}\right)
$$

where $\Delta$ is the difference operator and $\Delta P_{t}$ is equal to $\left(P_{t}-P_{t-1}\right)$. Equation (4) states that a change in the current price level is positively related to the present value of the expected changes in the money supply.

In the following, it is shown that future stream of money supply is, in turn, related to the future stream of budget deficits via the budget constraint of the government. The government's budget constraint in equation (5) expresses the relationship between budget deficits and money supply at a given period:

$$
G_{t}-T_{t}+r B_{t-1}=D e f_{t}=\Delta M_{t}+\Delta B_{t},
$$

where $G$ stands for government expenditures, $T$ is tax revenue, $B$ is the stock of interest-bearing government debt, $r$ is the nominal interest rate the government pays on the outstanding debt, and $\Delta M$ and $\Delta B$ are the changes in money supply and government debt, respectively. Def stands for the government's financing requirement: current expenditures plus interest payments on the outstanding debt minus tax revenues. Equation (5) states that each period the government has to finance its deficits either by issuing money or new debt. Hence, if the extent of either type of deficit financing is unknown a priori, there is no one-to-one correspondence between budget deficits and money creation in a given period. ${ }^{6}$

The article assumes that in any given period, the fraction, $\mu$, of budget deficits financed through monetary expansion is a negative

6. Forward solution of equation (5) under transversality condition indicates that an initial stock of debt should be financed either though the present value of a stream of money issue or budget surpluses. 
function of the degrees of both $\mathrm{CBI}$ and FMD: ${ }^{7}$

$$
\Delta M_{t}=\mu\left(G_{t}-T_{t}+\gamma B_{t-1}\right)=\mu D e f_{t},
$$

where $\mu=\{l C B I$ or $l F M D\}$ and $0 \leq \mu \leq 1$.

$l C B I$ and $l F M D$ stand for the lack of CBI and FMD, respectively, obtained by measuring the CBI and FMD indices on an inverted scale. Hence, the higher the value of $\mu$, the lower the degrees of either CBI or FMD. Equation (6), in conjunction with equation (5), implies that the degree of monetary accommodation of budget deficits is zero when the central bank is totally independent and the financial market is fully developed (that is, when $\mu$ is equal to zero). In such a case, all financing comes from debt issue. At the other extreme - that is, when CBI and FMD take their lowest values, or when $\mu$ is equal to one-all the financing to satisfy the budget constraint comes from monetary expansion.

By taking the expectations of both sides of equation (6) and substituting it in equation (4), one obtains equation (7), which states that inflation is a function of the present value of budget deficits: ${ }^{8}$

$$
\Delta P_{t}=(1 / \alpha) \sum_{i=0}^{\infty}(\beta / \alpha)^{i} \mu \cdot E\left(\operatorname{Def}_{t+i}\right)
$$

To estimate equation (7), one assumes that expectations about future budget deficits are formed by using all the relevant information available at time $t$. Following the related literature, inflation is thus estimated as a function of the lagged inflation rates, budget deficits, and the rates of money growth. To control for business cycles, the author also includes the growth rate of real output in the set of

7. As will be further explored in the next section, the measures of both CBI and FMD exhibit much less variance over time when compared to cross-country variation and, therefore, the notation excludes their time subscripts.

8. Obtaining a forward solution for the initial debt stock from the intertemporal budget constraint and substituting it in equation (4), one can write inflation in terms of an initial debt stock. One can thus estimate a version of equation (7) that has initial debt stock instead of deficit terms. The empirical section, however, does not report those estimation results not only because the sample of that experiment is rather limited both in size and country coverage but also because those results are possibly muddled by errors in data and measurement. Obtaining a measure of the debt stock that is both suitable and available for a cross-sectional analysis, however, is beyond the scope of this study. explanatory variables. To investigate the additional influence of both CBI and FMD on the inflationary effects of budget deficits, budget deficits $(D e f)$ are used also in interaction with the institutional variables, $l C B I$ and $l F M D$ (CBI and FMD, respectively, on an inverted scale). Denoting both $l C B I$ and $l F M D$ by $\mu$, one expresses the interaction term as $\mu$ Def. Because $\mu$ ranges between zero and one, $\mu$ Def reflects the weighed version of the Def term such that when CBI or FMD take their maximum values (when $\mu$ is 0 ), $\mu$ Def becomes zero and when either CBI or FMD is zero (when $\mu$ is 1), $\mu$ Def becomes Def itself.

Hence, equation (8) expresses the general form of the relationship to be estimated:

$$
\begin{aligned}
\pi_{t}= & f[A(L) \pi ; B(L) D e f ; C(L)(\mu D e f) ; \\
& D(L) g M ; E(L) g G D P]
\end{aligned}
$$

where $(L)$ is a lag operator and $A, B, C, D$, and $E$ indicate respective coefficient vectors.

\section{ESTIMATING THE RELATIONSHIP} BETWEEN BUDGET DEFICITS AND INFLATION

This section first describes the data and presents some observations on it. The author then tests the hypothesis that budget deficits lead to inflation especially when the degrees of central bank independence and financial market development are low by explaining the appropriate method for estimating the relationship derived in equation (8).

\section{A. Data}

To perform the empirical analysis, this article uses a pooled cross-section and time-series sample comprising 54 countries with 10-20 years of observations over the period of 1970-89. The basic economic data set consists of the annual average rate of change in consumer prices, budget deficits (or government financing requirement-measured on cash basis and inclusive of the nominal interest payments) in percentages of gross domestic product (GDP); the rate of growth of base money (currency plus bank reserves at the central bank); and the rate of growth of real GDP. ${ }^{9}$ All data is obtained from the

9. Easterly, Rodriguez and Schmidt-Hebbel (1994) provide data on consolidated fiscal deficits for 59 developed and less developed countries and measures of quasi-fiscal 
International Financial Statistics of the IMF and appear in country averages in Appendix Table A $1 .{ }^{10}$ Due to different coverages of timeseries across countries, the sample is called an unbalanced panel. ${ }^{11}$

The degrees of CBI and FMD are accounted for as follows. For CBI, the two indices constructed by Cukierman et al. (1992) are used: the legal index of CBI (legal-CBI) and the turnover rates of central bank governors $(T O R)$, the latter of which proxies the factual aspect of CBI.

Several indicators of financial market development are suggested in the literature (see, for example, Goldsmith, 1969; King and Levine, 1992; Ghani, 1992). Among them, this article uses the most commonly cited ones: credit extended to the private sector in ratio to the total credit of the financial system or to GDP, and the measures of financial deepening, namely, M1 or M2 in ratio to GDP. In addition, contract-intensive money (CIM) is used, which is the ratio of the noncurrency component of M2 to M2, as a measure of institutional development that is also positively associated with the level of financial market development (see Clague et al., 1995).

The higher the share of financial sector credit extended to the private sector (PRCR) the larger the private sector involvement in the economy and the less dependent the state sector on the financial sector. Hence, this author argues that this variable measures the degree of efficiency of the market mechanism, which reflects an important aspect of financial sector development. CIM reflects the degree of

deficits for 8 countries. Data for some of these countries are gathered from various sources other than the International Financial Statistics. The overlap of that sample with the sample of the current study is only 31 countries, half of which closely match with the data of the current study.

10. From the list of the countries reported in Appendix table A1, Italy and Botswana are excluded from the data set due to apparent lack of reliable information on budget deficits in these countries. Romania is also excluded from the sample due to lack of data on financial market development.

11. The composition of the panel data set is as follows:

\begin{tabular}{ll}
\hline 20 observations, & 36 countries; \\
19 observations, & 3 countries; \\
18 observations, & 5 countries; \\
16 observations, & 3 countries; \\
15 observations, & 1 country; \\
14 observations, & 2 countries; \\
12 observations, & 2 countries; and \\
10 observations, & 2 countries. \\
\hline
\end{tabular}

confidence in the financial system and thus also provides a measure of FMD. Although the ratio of broad money to GDP (M2) is used as a measure of financial deepening, the author also argues that it may not reflect financial market development if there is monetary overhang or if a large component of broad money is foreign currency. To minimize the measurement errors and possible biases involved in the various measures of $\mathrm{CBI}$ or FMD, however, the author uses all these indicators jointly in the empirical analysis (source, IMF International Financial Statistics). ${ }^{12}$

To obtain estimates that are easy to interpret, before using the institutional indices in interaction with Def, the author normalizes each index between zero and one-on an inverted scale. As a result, the index takes the value of one to indicate the complete lack of $\mathrm{CBI}$ or FMD (that is, $C B I=0$ or $F M D=0$, implying $l C B I=1$ or $l F M D=1)$, whereas zero indicates full CBI or FMD (that is, $C B I=1$ or $F M D=1$, implying $l C B I=0$ or $l F M D=0) .{ }^{13}$

12. All these indices correlate rather weakly (see Appendix Table A2). The legal-CBI index is based on the articles of central bank laws and, being a rough proxy for the actual degree of independence, its correlation with FMD is very low. Turnover rates of central bank presidents, on the other hand, exhibit closer correlations with the FMD indices. One does not, however, necessarily expect a close association between the indices of FMD and CBI, because in countries where FMD is low, a low turnover rate may be due to a subservient monetary authority. In addition, in countries where FMD is high, the degree of CBI may be low if either the government is itself highly inflation-averse or the availability of noninflationary means of finance makes CBI less important.

13. The conversion process is as follows: to normalize the legal-CBI index, for example, between zero and one, each value of the index is divided by the maximum value that it takes in the overall sample. To invert the scale, such that one means complete lack of independence, subtract the resulting number from one. The author further divides the resultant series by its maximum value to make the minimum value of the initial series one. Because, unlike legal-CBI or FMD, the higher values of TOR already means lower CBI, the inversion of scale is not necessary for TOR. Hence, the normalization and inversion processes can be formulated as follows:

$$
\begin{aligned}
& C B I_{i}=\left(1-\left[\text { legal-CBI } /\left(\text { legal }-C B I_{\max }\right]\right) /(1-[\text { legal- }\right. \\
& \left.\left.C B I_{i} /(\text { legal-CBI })_{\max }\right]\right)_{\max } \\
& T O R_{i}=\left[T O R_{i} / T O R_{\max }\right] \\
& F M D_{i}=\left[1-\left(F M D_{i} / F M D_{\max }\right)\right] /\left[1-\left(F M D_{i} /\right.\right. \\
& \left.\left.F M D_{\max }\right)\right]_{\max }
\end{aligned}
$$

where $C B I$ stands for legal-CBI; FMD stands for any of the three indicators of financial market development; and $i, i=1 \ldots \mathrm{m}$, is the number of observations. 
Appendix table A2 reports these data in the form of cross-section averages. ${ }^{14}$

Before proceeding with the estimation, it is worthwhile to note there may be additional sources of data deficiencies that could also lead to some biases in the estimation. First, the legal measure of CBI (based on central bank laws) is an insufficient measure of the actual degree of CBI. Developing factual measures of CBI are therefore likely to improve the estimation results. Second, data on fiscal deficits, especially in less developed countries, generally suffer from measurement problems.

\section{B. Some Observations}

Ordinary least squares (OLS) estimations, using either time-series or panel data, do not reveal any significant contemporaneous relationship between budget deficits and inflation. Various factors might contribute to the apparent lack of contemporaneous correlation between budget deficits and inflation. In addition to delays in interest payments and increases in quasi-fiscal deficits, which are not reflected in the budget deficits data, some of those factors are listed. First, monetary authorities that face high budget deficits might tighten monetary policy to eliminate inflation. This may lead to a negative (rather than a positive) association between budget deficits and inflation. Belgium in 1985, Barbados in 1976 and 1984, Japan in 1975, Greece in 1988, Honduras in 1984, and Malaysia in 1975 are some examples of monetary tightening in the face of increasing budget deficits, which in turn led to lower rates of inflation. Second, building pressures for the monetization of budget deficits may not affect the inflationary expectations of the public for some period of time. Thus, in the short run, budget deficits can be financed through increasing government debt, without necessarily generating much effect on inflation. Hence, an increase in budget deficits does not necessarily lead to a contemporaneous increase in the inflation rate, even though it may have a lagged effect.

These arguments indicate that an appropriate analysis of the relationship between budget

14. The author notes that both legal-CBI and TOR are reported in decade averages in Cukierman et al. (1990). Given that this study employs annual data, the author takes into account the actual dates of change of the central bank laws to express legal-CBI as a yearly series. Because $T O R$ refers to frequencies of change over a decade in Cukierman et al. (1992), TOR is repeated for every year over the periods they are originally reported. deficits and inflation requires an intertemporal analysis. Moreover, because merely using a time-series analysis would ignore the crosssectional variation in institutional characteristics, this article examines this relationship in a panel sample that exhibits considerable variation in both economic and institutional characteristics. To capture such institutional characteristics, the author explicitly takes into account the indices of CBI and FMD. ${ }^{15}$ Moreover, by allowing a different constant term for each country, one can take into account the possible effects of other structural factors as well. ${ }^{16}$

Inflation series exhibit a large variance both across the panel sample (see Appendix table A1) and within some countries. To eliminate possible biases this may generate and to increase efficiency, the author uses a transformed version of inflation, denoted by $D$, which is expressed as $D=\pi /(1+\pi)$, where $D$ stands for the real rate of depreciation in money stock. $D$ has a one-to-one correspondence with the inflation rate and ranges between zero and one. ${ }^{17}$

\section{Estimation with Panel Data Set}

The hypothesis is tested by estimating the relationship in equation (8) using a sample of 54 countries and 1,002 observations. The estimation method that accommodates both the dynamic nature of the equation and the use of an unbalanced panel data set has been developed by Arellano and Bond (1988) and involves the use of GMM as will be further explained.

Using the notation in equation (8), the estimable relationship in equation (9) is written:

$$
\begin{aligned}
D_{i t}= & \sum_{j=1}^{q} a_{1 j} D_{i(t-j)}+\sum_{j=1}^{q} a_{2 j} D e f_{i(t-j)} \\
& +\sum_{j=1}^{q} a_{3 j}\left[\mu D e f_{i(t-j)}\right]+\sum_{j=1}^{q} a_{4 j} g M_{i(t-j)} \\
& +\sum_{j=1}^{q} a_{5 j} g G D P_{i(t-j)}+\eta_{i}+v_{i t}
\end{aligned}
$$

15. The indices of CBI and FMD do not generally exhibit large variations over time within a cross-section, especially given that the length of the time period used for this study is not more than two decades per country.

16. As will be explained in the next section, however, the estimation method requires first differencing, as a result of which these terms drop out.

17. Cukierman et al. (1992) introduce this variable for similar reasons. 
where $i, i=1 \ldots N$, and $t, t=1 \ldots T$, refer to country and time periods respectively. $q$ refers to the maximum lags of the right-hand side variables; $\eta$ is the country-specific fixed effects; and $v$ is the error term. ${ }^{18}$ The rest of the notation follows that of section II. ${ }^{19}$ The coefficient of the interaction term $\mu D e f$ is expected to capture the role of institutions on the relationship between budget deficits and inflation. ${ }^{20}$

The article estimates mainly two versions of equation (9): first by excluding the growth of base money (assuming $a_{4} \mathrm{~s}$ are equal to zero) and then by including it. By means of these two different specifications, the author investigates the direct and indirect (through base money growth) effects of budget deficits on inflation. If the coefficients of both budget deficits and money growth are significant, it implies that budget deficits have a direct effect on inflation, in addition to their indirect effect on inflation through monetary expansion. That is, even if budget deficit is not accommodated with monetary expansion in a given year, it may lead to a higher inflation rate due to expectations of future money growth. It is hypothesized that the $\mu$ Def terms capture such expectations.

Because the possibility of fixed effects biases the OLS estimation, the estimation is performed by taking the first differences of both sides of equation (9) to eliminate countryspecific fixed effects. ${ }^{21}$ Because this leads to a first-order serial correlation in the error terms (assuming white-noise errors in the original model), however, the article uses an instrumental variables technique. ${ }^{22}$ The instrument set includes the first and second moments, constructed by the GMM technique (see Arellano and Bond, 1988), of the further lags of the

18. Although $\mu$ is denoted as a constant parameter, based on the observation that CBI and FMD indices generally have low variability over time, it is allowed to vary in the estimations.

19. Appendix Table A3 further provides the list and the description of the variables used in estimating equation (9).

20. Each of the indices of CBI and FMD (the inverse of which are denoted by $\mu$ ) are used as weighing factors, where the higher the degrees of CBI and FMD, the lower the weights.

21. Among the possible fixed effects are the degree of political instability and the type of exchange rate regime.

22. Nickell (1981) shows that OLS estimation with panel data yields inconsistent estimators when individual-specific fixed effects exist and lagged dependent variables are used as explanatory variables. He demonstrates in such cases that a basic assumption of OLS estimationnamely, the independence between RHS variables and the error term - is violated. dependent variable than those that appear on the right-hand side. The rest of the explanatory variables are also in the instrument set.

Equation specification, or the appropriate lag lengths, are tested for by testing the hypotheses that instruments are not correlated with the error term and that there is no seconddegree serial correlation. The test statistics used for these hypotheses are $s$ (Sargan test) and $m_{2}$, respectively. Based on these specification tests, a two-period lagged model is chosen $(q=2)$ for equation (9). That is, using a two-period lagged model, one cannot reject, within the standard levels of confidence, the hypotheses that the set of instruments are uncorrelated with the error terms and that there is no second-order serial correlation (due to Sargan and $m_{2}$ tests, respectively). $^{23}$

The Wald statistic reported in Table 1 provides a significance test for the lagged effects of budget deficits on inflation; in runs I and II the test refers to the joint significance of the $a_{2}$ coefficients and in runs III and IV it refers to the joint significance of $a_{3}$ coefficients. The five different $\mu D$ ef terms in equation (9) are labeled DefCBI, DefTOR, DefPRCR, DefM2, and DefCIM, each representing the interaction of budget deficits with the inverted and normalized series of the two CBI and the three FMD indicators, respectively. ${ }^{24}$

In Table 1 are reported four different runs of equation (9)-labeled from I to IV. In both runs I and II, observe that the lagged effects of budget deficits on inflation are positive and significant, as indicated both by the $t$-ratios and by the Wald test for joint significance. Run II indicates that controlling for money growth $(g M)$ improves their significance. ${ }^{25}$ Run II also shows the expected positive effect of base money growth on inflation on the second

23. Based on these criteria, the author rejects the model with more than two lags.

24. As explained in Part III A, the CBI and the FMD indicators are: the law-based CBI index (legal-CBI), turnover rates of central bank governors (TOR), the share of banking sector credit to the private sector in total banking sector credit $(P R C R), \mathrm{M} 2$ to GDP ratio (M2), and the contract intensive money (CIM).

25. The estimation results in run II indicate that a 1-percentage-point increase in both the first and second lag of fiscal deficits on average lead to 2.3 points increase in the value of $D$ (calculated as the product of the average of lagged deficits and the sum of $a_{2}$ coefficients). This amounts to about 2.5-percentage-point increase in the inflation rate for inflation rates of up to $10 \%$, about 3.5 percentage points' increase in the inflation rate for inflation rates of up to $50 \%$ and about 8.5 percentage points' increase in the inflation rate for inflation rates of up to $100 \%$ on average. 
TABLE 1

Estimation of Inflation in a Panel of 54 Countries

\begin{tabular}{|c|c|c|c|c|}
\hline \multirow[b]{2}{*}{ RHS Variables } & \multicolumn{4}{|c|}{ Dependent Variable: $D$} \\
\hline & (I) & (II) & (III) & (IV) \\
\hline $\begin{array}{l}D(-1) \\
(t \text {-stat })\end{array}$ & $\begin{array}{c}0.46 \\
(20.86)\end{array}$ & $\begin{array}{c}0.34 \\
(18.52)\end{array}$ & $\begin{array}{c}0.42 \\
(22.43)\end{array}$ & $\begin{array}{c}0.33 \\
(13.82)\end{array}$ \\
\hline$D(-2)$ & $\begin{array}{c}-0.16 \\
(-13.19)\end{array}$ & $\begin{array}{c}-0.20 \\
(-18.36)\end{array}$ & $\begin{array}{c}-0.14 \\
(-11.55)\end{array}$ & $\begin{array}{c}-0.19 \\
(-17.08)\end{array}$ \\
\hline $\operatorname{Def}(-1)$ & $\begin{array}{c}0.23 \\
(5.92)\end{array}$ & $\begin{array}{c}0.28 \\
(9.54)\end{array}$ & $\begin{array}{l}-0.72 \\
(-0.93)\end{array}$ & $\begin{array}{l}-1.08 \\
(-1.53)\end{array}$ \\
\hline $\operatorname{Def}(-2)$ & $\begin{array}{c}0.18 \\
(3.72)\end{array}$ & $\begin{array}{c}0.19 \\
(4.97)\end{array}$ & $\begin{array}{l}-1.51 \\
(-1.97)\end{array}$ & $\begin{array}{l}-1.98 \\
(-2.66)\end{array}$ \\
\hline $\operatorname{DefCBI}(-1)$ & & & $\begin{array}{c}0.28 \\
(1.17)\end{array}$ & $\begin{array}{c}0.11 \\
(0.31)\end{array}$ \\
\hline $\operatorname{DefCBI}(-2)$ & & & $\begin{array}{l}-0.14 \\
(-0.80)\end{array}$ & $\begin{array}{l}-0.09 \\
(-0.41)\end{array}$ \\
\hline $\operatorname{DefTOR}(-1)$ & & & $\begin{array}{c}0.92 \\
(6.68)\end{array}$ & $\begin{array}{c}0.75 \\
(5.86)\end{array}$ \\
\hline $\operatorname{DefTOR}(-2)$ & & & $\begin{array}{c}0.40 \\
(1.87)\end{array}$ & $\begin{array}{c}0.64 \\
(2.82)\end{array}$ \\
\hline $\operatorname{DefPRCR}(-1)$ & & & $\begin{array}{c}3.46 \\
(2.94)\end{array}$ & $\begin{array}{l}4.68 \\
(3.82)\end{array}$ \\
\hline $\operatorname{DefPRCR}(-2)$ & & & $\begin{array}{c}2.89 \\
(1.75)\end{array}$ & $\begin{array}{l}3.60 \\
(2.24)\end{array}$ \\
\hline $\operatorname{DefM} 2(-1)$ & & & $\begin{array}{l}-1.64 \\
(-6.76)\end{array}$ & $\begin{array}{l}-1.66 \\
(-7.45)\end{array}$ \\
\hline $\operatorname{DefM} 2(-2)$ & & & $\begin{array}{l}-0.01 \\
(-0.12)\end{array}$ & $\begin{array}{c}0.08 \\
(0.42)\end{array}$ \\
\hline $\operatorname{DefCIM}(-1)$ & & & $\begin{array}{c}0.41 \\
(1.25)\end{array}$ & $\begin{array}{c}0.32 \\
(1.14)\end{array}$ \\
\hline $\operatorname{DefCIM}(-2)$ & & & $\begin{array}{c}0.88 \\
(5.83)\end{array}$ & $\begin{array}{c}0.94 \\
(5.20)\end{array}$ \\
\hline$g M(-1)$ & & $\begin{array}{c}0.00 \\
(-1.16)\end{array}$ & & $\begin{array}{l}-0.01 \\
(-3.52)\end{array}$ \\
\hline$g M(-2)$ & & $\begin{array}{c}0.02 \\
(15.69)\end{array}$ & & $\begin{array}{c}0.02 \\
(9.38)\end{array}$ \\
\hline$g G D P(-1)$ & $\begin{array}{c}0.05 \\
(2.32)\end{array}$ & $\begin{array}{c}0.01 \\
(0.67)\end{array}$ & $\begin{array}{c}0.03 \\
(1.10)\end{array}$ & $\begin{array}{l}-0.01 \\
(-0.55)\end{array}$ \\
\hline$g G D P(-2)$ & $\begin{array}{c}0.02 \\
(0.67)\end{array}$ & $\begin{array}{c}0.01 \\
(0.44)\end{array}$ & $\begin{array}{c}0.01 \\
(0.29)\end{array}$ & $\begin{array}{c}-0.01 \\
(0.30)\end{array}$ \\
\hline Sargan test (d.f.) & $\begin{array}{l}41.41 \\
(31)\end{array}$ & $\begin{array}{l}40.74 \\
(31)\end{array}$ & $\begin{array}{l}44.34 \\
(31)\end{array}$ & $\begin{array}{l}43.93 \\
(31)\end{array}$ \\
\hline m2 (d.f.) & $\begin{array}{l}-0.31 \\
(54)\end{array}$ & $\begin{array}{l}0.025 \\
(54)\end{array}$ & $\begin{array}{l}-0.554 \\
(54)\end{array}$ & $\begin{array}{l}-0.00 \\
(54)\end{array}$ \\
\hline Wald test (d.f.) & $\begin{array}{l}43.25 \\
(2)\end{array}$ & $\begin{array}{l}103.77 \\
(2)\end{array}$ & $\begin{array}{r}4189 \\
(10)\end{array}$ & $\begin{array}{r}4077 \\
(10)\end{array}$ \\
\hline
\end{tabular}

lag. The positive effect of one-period lagged monetary growth on inflation, however, may have been captured by the first lag of the $D$ term. Although the effect on $D$ of its own second lag appears negative in both I and II, in both runs the overall lagged effect of $D$, observed by the sum of the coefficients of its two lags, is positive.
In runs III and IV, as the coefficients of budget deficits themselves become either negative or insignificant, the sum of the coefficients of the interactive terms ( $\mu$ Def terms) is both positive and highly significant. In addition, $T O R, P R C R$, and CIM, in particular, account for this effect. As a separate experiment, the $\mu$ Def terms are entered individually into the 
regressions (not reported), rather than all five of them as in run IV, along with the lagged $D$, $g M$, and Def terms. This led to more significant results, though similar in nature, for the $\mu D e f$ terms, except for DefCBI, which is not significant, than those reported in run IV. Though the negative and significant coefficient of the first DefM2 term gains more significance in this experiment, the second lag of it becomes positively significant. Moreover, the summation across both the first lags and the second lags of DefM2 and Def are positive. The negative significance of the first lag of DefM2 term in run IV may thus be interpreted as being due to either the high collinearity among the $\mu$ Def terms or to the failure of the M2 series to proxy the degree of financial sector development, as already discussed in section IIIA, or a combination of these factors. In conclusion, however, it should be noted that the Wald test for the joint significance of the interactive Def terms in runs III and IV is substantially higher than the Def terms in runs I and II.

The sum of the coefficients of the two lags of base money growth is positive and significant, as expected. On the other hand, the lags of the growth rate of real GDP, do not affect $D$ significantly. In conclusion, the test results reported in Table 1 suggest that the positive lagged effects of budget deficits on inflation are mainly due to the lack of central bank independence and financial market development.

\section{Sensitivity Tests}

The robustness of the findings are tested by repeating the experiments in subsets of the sample. Subsets of the sample are generated by excluding very high (more than 100\%) and high (more than 50\%) rates of inflation. This way of defining subsamples results in samples of size 910 and 805, with crosssectional sizes of 51 and 45, respectively. Investigating the relationship between budget deficits and inflation in subsamples that are distinguished on the basis of the dependent variable, however, may introduce a sample selection bias. Nonetheless, if one observes that the nature of the relationship between budget deficits and inflation are different in these subsets, the results of Table 1 would need to be viewed with caution.

The estimations reported in Table 1 are repeated in a sample that excludes very high and hyperinflationary episodes, ${ }^{26}$ which amount to 92 observations. Next, the analysis looks at a smaller sample that excludes observations with inflation rates exceeding $50 \%$, reducing the total sample size by 197 observations. Table 2 reports those results in a slightly different format than in Table 1 because the reduced cross-sectional sizes of the subsets only allow for part of the right-hand-side variables to be included in the regression at a time. To perform the estimations in a comparable manner, the author therefore only includes the $D$, Def, $g M$, and either of the CBI and FMD indicator sets (either two of the CBI or three of the FMD indicators) in interaction with the Def term at a time. To show that these results would not differ much from the results that one would obtain if one were to estimate them jointly in the regression, the author also reports (runs I and II) the result of the estimation using the unrestricted sample.

The main observations based on Table 2 are as follows. First, a comparison of runs I and II in Table 2 to run IV of Table 1 reveals that estimating the regression by groups of explanatory variables yields virtually the same results as their joint estimation. Given this, we next observe in runs III and VII that, as compared to the overall sample (run I of Table 1), the positively significant effect of lagged effect of deficits on inflation gets weaker in the sample that excludes more than $100 \%$ inflation rates; it even disappears in the sample that excludes more than $50 \%$ inflation rates. In the sample that excludes more than $100 \%$ inflation rates, similar to the results in the overall sample that are reported in Table 1, the positive significance of lagged deficits on inflation is mainly due to the lack of CBI and FMD, especially when measured by $T O R, M 2$, and $\mathrm{CIM}^{27}$ Finally, when the analysis takes an even smaller subset of the sample, excluding

26. Very high inflation or hyperinflationary periods are defined as more than $100 \%$ yearly average inflation rate. Within that sample, observations with $200 \%$ or more inflation rates also coincide with the acceleration of inflation by more than $100 \%$ a year. Such high inflationary cases are observed in Argentina in both the 1970s and the 1980s, in Brazil after 1985, in Chile between 1970 and 1976, in Israel after 1984, in Nicaragua after 1985, in Peru after 1988, and in Yugoslavia for 1989. Argentina, Chile, Israel, and Nicaragua also had fiscal deficits of more than $10 \%$ of GDP prior to those years.

27. In the unrestricted sample, the interactions of deficits with TOR, PRCR, and CIM are significant. In restricted samples, however, observe that $M 2$, rather than $P R C R$, along with $T O R$ and CIM in interaction with deficits appear positively significant. 
TABLE 2

Estimation of Inflation in Subsets of the Sample

\begin{tabular}{|c|c|c|c|c|c|c|c|c|}
\hline \multirow[b]{3}{*}{ RHS Variables } & \multicolumn{8}{|c|}{ Dependent Variable: $D$} \\
\hline & \multicolumn{2}{|c|}{ Whole Sample } & \multicolumn{3}{|c|}{$(\operatorname{Inf} \leq 100)$} & \multicolumn{3}{|c|}{$(\operatorname{Inf} \leq 50)$} \\
\hline & (I) & (II) & (III) & (IV) & (V) & (VI) & (VI) & (VII) \\
\hline $\begin{array}{l}D(-1) \\
(t \text {-stat })\end{array}$ & $\begin{array}{c}0.35 \\
(18.93)\end{array}$ & $\begin{array}{c}0.35 \\
(12.65)\end{array}$ & $\begin{array}{c}0.33 \\
(19.50)\end{array}$ & $\begin{array}{c}0.35 \\
(19.09)\end{array}$ & $\begin{array}{c}0.34 \\
(19.09)\end{array}$ & $\begin{array}{c}0.32 \\
(11.66)\end{array}$ & $\begin{array}{c}0.32 \\
(12.84)\end{array}$ & $\begin{array}{c}0.32 \\
(10.87)\end{array}$ \\
\hline$D(-2)$ & $\begin{array}{c}-0.19 \\
(-17.94)\end{array}$ & $\begin{array}{c}-0.21 \\
(-18.76)\end{array}$ & $\begin{array}{l}-0.19 \\
(-8.18)\end{array}$ & $\begin{array}{l}-0.19 \\
(-7.79)\end{array}$ & $\begin{array}{l}-0.21 \\
(-8.04)\end{array}$ & $\begin{array}{c}-0.19 \\
(-12.53)\end{array}$ & $\begin{array}{c}-0.18 \\
(-11.25)\end{array}$ & $\begin{array}{c}-0.19 \\
(-11.34)\end{array}$ \\
\hline $\operatorname{Def}(-1)$ & $\begin{array}{c}0.08 \\
(0.81)\end{array}$ & $\begin{array}{l}-0.5 \\
(-0.79)\end{array}$ & $\begin{array}{c}0.07 \\
(2.62)\end{array}$ & $\begin{array}{l}-0.24 \\
(-2.79)\end{array}$ & $\begin{array}{l}-0.06 \\
(-0.29)\end{array}$ & $\begin{array}{c}0.00 \\
(0.01)\end{array}$ & $\begin{array}{l}-0.26 \\
(-3.29)\end{array}$ & $\begin{array}{c}0.05 \\
(0.27)\end{array}$ \\
\hline $\operatorname{Def}(-2)$ & $\begin{array}{c}0.04 \\
(0.46)\end{array}$ & $\begin{array}{l}-1.6 \\
(-1.97)\end{array}$ & $\begin{array}{c}0.09 \\
(2.57)\end{array}$ & $\begin{array}{c}0.29 \\
(2.46)\end{array}$ & $\begin{array}{l}-0.21 \\
(-0.94)\end{array}$ & $\begin{array}{c}0.00 \\
(0.09)\end{array}$ & $\begin{array}{c}0.22 \\
(2.63)\end{array}$ & $\begin{array}{l}-0.10 \\
(-0.56)\end{array}$ \\
\hline $\operatorname{DefCBI}(-1)$ & $\begin{array}{c}0.15 \\
(0.88)\end{array}$ & & & $\begin{array}{l}0.35 \\
(2.45)\end{array}$ & & & $\begin{array}{c}0.35 \\
(3.25)\end{array}$ & \\
\hline $\operatorname{DefCBI}(-2)$ & $\begin{array}{c}-0.07 \\
(-0.55)\end{array}$ & & & $\begin{array}{c}-0.57 \\
(-3.49)\end{array}$ & & & $\begin{array}{c}-0.37 \\
(-4.12)\end{array}$ & \\
\hline $\operatorname{DefTOR}(-1)$ & $\begin{array}{l}0.5 \\
(6.68)\end{array}$ & & & $\begin{array}{c}0.57 \\
(5.81)\end{array}$ & & & $\begin{array}{c}0.35 \\
(4.32)\end{array}$ & \\
\hline $\operatorname{DefTOR}(-2)$ & $\begin{array}{c}0.85 \\
(4.18)\end{array}$ & & & $\begin{array}{c}0.31 \\
(1.43)\end{array}$ & & & $\begin{array}{l}-0.18 \\
(-0.74)\end{array}$ & \\
\hline $\operatorname{Def} P R C R(-1)$ & & $\begin{array}{c}3.96 \\
(3.33)\end{array}$ & & & $\begin{array}{c}-0.07 \\
(-0.17)\end{array}$ & & & $\begin{array}{r}0.66 \\
(-2.44)\end{array}$ \\
\hline $\operatorname{Def} P R C R(-2)$ & & $\begin{array}{c}2.85 \\
(1.52)\end{array}$ & & & $\begin{array}{c}-0.42 \\
(-0.98)\end{array}$ & & & $\begin{array}{l}-1.16 \\
(-4.87)\end{array}$ \\
\hline $\operatorname{DefM} 2(-1)$ & & $\begin{array}{l}-1.68 \\
(-7.82)\end{array}$ & & & $\begin{array}{l}-0.01 \\
(-0.16)\end{array}$ & & & $\begin{array}{c}0.20 \\
(1.53)\end{array}$ \\
\hline $\operatorname{DefM} 2(-2)$ & & $\begin{array}{c}0.22 \\
(1.09)\end{array}$ & & & $\begin{array}{c}0.44 \\
(3.22)\end{array}$ & & & $\begin{array}{c}0.51 \\
(3.17)\end{array}$ \\
\hline $\operatorname{DefCIM}(-1)$ & & $\begin{array}{c}0.45 \\
(1.73)\end{array}$ & & & $\begin{array}{c}0.58 \\
(3.86)\end{array}$ & & & $\begin{array}{c}0.44 \\
(3.44)\end{array}$ \\
\hline $\operatorname{DefCIM}(-2)$ & & $\begin{array}{c}0.87 \\
(4.63)\end{array}$ & & & $\begin{array}{c}0.55 \\
(5.25)\end{array}$ & & & $\begin{array}{c}0.88 \\
(15.14)\end{array}$ \\
\hline$g M(-1)$ & $\begin{array}{l}-0.01 \\
(-3.03)\end{array}$ & $\begin{array}{l}-0.00 \\
(-2.14)\end{array}$ & $\begin{array}{c}0.03 \\
(4.84)\end{array}$ & $\begin{array}{c}0.02 \\
(4.28)\end{array}$ & $\begin{array}{c}0.03 \\
(5.51)\end{array}$ & $\begin{array}{c}0.01 \\
(2.16)\end{array}$ & $\begin{array}{c}0.01 \\
(2.07)\end{array}$ & $\begin{array}{c}0.01 \\
(2.61)\end{array}$ \\
\hline$g M(-2)$ & $\begin{array}{c}0.01 \\
(13.21)\end{array}$ & $\begin{array}{r}0.02 \\
(13.0)\end{array}$ & $\begin{array}{c}0.02 \\
(5.59)\end{array}$ & $\begin{array}{c}0.02 \\
(4.56)\end{array}$ & $\begin{array}{c}0.03 \\
(5.96)\end{array}$ & $\begin{array}{c}0.01 \\
(3.34)\end{array}$ & $\begin{array}{c}0.01 \\
(2.89)\end{array}$ & $\begin{array}{c}0.02 \\
(5.14)\end{array}$ \\
\hline Sargan test (d.f.) & $\begin{array}{l}40.8 \\
(31)\end{array}$ & $\begin{array}{l}45.14 \\
(31)\end{array}$ & $\begin{array}{l}45.07 \\
(31)\end{array}$ & $\begin{array}{l}44.46 \\
(31)\end{array}$ & $\begin{array}{l}45.26 \\
(31)\end{array}$ & $\begin{array}{l}41.59 \\
(31)\end{array}$ & $\begin{array}{l}41.45 \\
(31)\end{array}$ & $\begin{array}{l}41.98 \\
(31)\end{array}$ \\
\hline
\end{tabular}


TABLE 2 continued

\begin{tabular}{|c|c|c|c|c|c|c|c|c|}
\hline \multirow[b]{3}{*}{ RHS Variables } & \multicolumn{8}{|c|}{ Dependent Variable: $D$} \\
\hline & \multicolumn{2}{|c|}{ Whole Sample } & \multicolumn{3}{|c|}{$(\operatorname{Inf} \leq \mathbf{1 0 0 )}$} & \multicolumn{3}{|c|}{$(\operatorname{Inf} \leq \mathbf{5 0})$} \\
\hline & (I) & (II) & (III) & (IV) & (V) & (VI) & (VI) & (VII) \\
\hline $\mathbf{m} 2$ (d.f.) & $\begin{array}{l}-0.091 \\
(54)\end{array}$ & $\begin{array}{l}0.261 \\
(54)\end{array}$ & $\begin{array}{l}-0.538 \\
(51)\end{array}$ & $\begin{array}{l}-0.621 \\
(51)\end{array}$ & $\begin{array}{l}-0.351 \\
(51)\end{array}$ & $\begin{array}{l}-1.20 \\
(45)\end{array}$ & $\begin{array}{l}-1.247 \\
(45)\end{array}$ & $\begin{array}{l}-1.17 \\
(45)\end{array}$ \\
\hline Wald test (d.f.) & $\begin{array}{l}72.79 \\
(4)\end{array}$ & $\begin{array}{c}1657.4 \\
\text { (6) }\end{array}$ & $\begin{array}{l}13.2 \\
\text { (2) }\end{array}$ & $\begin{array}{l}67.39 \\
(4)\end{array}$ & $\begin{array}{l}75.92 \\
(6)\end{array}$ & $\begin{array}{l}0.01 \\
(2)\end{array}$ & $\begin{array}{l}64.94 \\
(4)\end{array}$ & $\begin{array}{l}317.98 \\
(6)\end{array}$ \\
\hline
\end{tabular}


the observations with more than $50 \%$ inflation rates, even though the positive significant effect of deficits on inflation disappears, one can still observe that $\mathrm{CBI}$ and FMD weighed deficit terms still have positive significant effects on $D$. As in the sample that excludes more than $100 \%$ inflation rates, in this sample, too, deficits appear to affect inflation positively in cases of a high TOR and low $M 2$ and CIM. This observation indicates that even though, on average, the deficit inflation linkage seems to break down in cases of relatively low inflation rates, the positive relationship obtains in cases of the lack of CBI and FMD.

Another, and perhaps a more natural, way to conduct a sensitivity analysis for the results reported in Tables 1 and 2 would be to test whether there are differences between the developed and less developed country subsamples. This type of partitioning of the data leads to the number of cross-sections of 19 and 35, and the sample sizes of 326 and 628 for the developed and less developed subsamples, respectively. These sample sizes, however, prevent the replication of the estimations reported earlier. A sensitivity test is nevertheless performed.

The robustness of the findings are investigated by looking separately at the less developed sample. Due to the lack of sufficient degrees of freedom to replicate the run IV in Table 1, however, in this subsample estimations are performed by using one type of $\mu$ Def terms at a time. ${ }^{28}$ The results (not reported) are similar in nature to those obtained in the entire sample that are reported in Table 1. This further supports the robustness of the findings. Interestingly, however, along with DefCBI terms, DefTOR terms also appear insignificant in the sample of less developed countries. By contrast, especially the second lag of DefCIM term, and though its significance level declines, the first lag of DefPRCR both appear positively significant in this subsample, too. The first term of the DefM2 remains negatively significant as in the entire sample.

To summarize, these findings suggest that budget deficits have significant predictive

28. The nature of the estimation technique employed here does not permit a separate estimation in the developed country subset, which consists of 19 countries in the current sample, due to the lack of sufficient degrees of freedom. power for inflation, especially when coupled with the lack of central bank independence and financial market development. Sensitivity tests suggest that this finding is generally robust to different sample characteristics.

\section{CONCLUSIONS}

The main hypothesis of this study is that budget deficits lead to inflation primarily when the central bank is not independent and when the financial market is not developed. The current empirical analysis explores the relationship between budget deficits and inflation in a sample of 54 developed and less developed countries, each with 10 to 20 years. This analysis explicitly accounts for the varying degrees of CBI and FMD.

In view of the factors that may conceal or eliminate the contemporaneous relationship between budget deficits and inflation, this article investigates their lagged relationship. To overcome possible estimation problems due to the dynamic nature of the relationship and the unbalanced nature of the panel, the estimation is performed in first differences, using a two-stage procedure by which instruments are formed by GMM.

Estimation results suggest that budget deficits have a significant positive effect on inflation. The results also suggest, however, that this effect is largely attributable to low degrees of CBI and FMD. This finding is also robust to sample selection; in the absence of CBI and FMD, deficits have a positive effect on inflation in high as well as in low inflation samples. Even though we observe that in samples with relatively low inflation rates (less than $50 \%$ ) deficits do not, on average, have a positive effect on inflation, this effect recovers when one accounts for the degree of CBI and FMD. The findings remain generally similar in nature in the less developed countries as in the entire sample as well.

Having found supportive evidence for the hypothesis, the author nonetheless notes that the reliability of the findings of this study may somewhat be limited by data deficiencies. In particular, obtaining a reliable and comprehensive set of fiscal deficits data that is defined over a large number of countries remains to be a challenge for improving the findings of this study. 
APPENDIX TABLE A1

Data Averages, Coverage, and Contemporaneous Correlations between Budget Deficits and Inflation

\begin{tabular}{|c|c|c|c|c|c|}
\hline Country & $\begin{array}{c}\text { Inflation } \\
(\%, \text { Annual Average })\end{array}$ & $\begin{array}{c}\text { Deficits } \\
\text { (\% of GDP, Average) }\end{array}$ & $\begin{array}{c}\text { Base Money Growth } \\
\text { (Average) }\end{array}$ & $\begin{array}{l}\text { Correlation between } \\
\text { Infl. and Deficits }\end{array}$ & Time Period \\
\hline Australia & 9.1 & 1.5 & 10.1 & 0.22 & $1970-89$ \\
\hline Austria & 5.0 & -3.6 & 6.8 & 0.06 & $1970-89$ \\
\hline Belgium & 6.0 & 7.3 & 4.6 & -0.01 & $1970-89$ \\
\hline Chile & 98.0 & 1.5 & 117.4 & 0.07 & $1970-89$ \\
\hline Costa Rica & 18.4 & 2.9 & 30.0 & -0.13 & $1970-89$ \\
\hline Germany & 3.9 & 1.2 & 7.7 & -0.01 & $1970-89$ \\
\hline Denmark & 8.1 & 0.4 & 11.3 & 0.18 & $1970-89$ \\
\hline Ethiopia & 7.5 & 4.9 & 12.4 & -0.00 & $1970-89$ \\
\hline Finland & 8.9 & 0.6 & 19.0 & 0.02 & $1970-89$ \\
\hline France & 8.1 & 1.5 & 8.2 & 0.01 & $1970-89$ \\
\hline Greece & 15.9 & 6.6 & 19.7 & 0.07 & $1970-89$ \\
\hline Honduras & 7.0 & 3.6 & 12.0 & -0.05 & $1970-89$ \\
\hline India & 8.3 & 5.7 & 15.4 & -0.01 & $1970-89$ \\
\hline Ireland & 11.1 & 10.0 & 12.9 & 0.42 & $1970-89$ \\
\hline Israel & 81.1 & 15.1 & 97.6 & 0.00 & $1970-89$ \\
\hline Japan & 5.8 & 4.4 & 11.5 & -0.12 & $1970-89$ \\
\hline Korea (South) & 11.8 & 1.3 & 24.2 & 0.25 & $1970-89$ \\
\hline Malaysia & 4.6 & 9.0 & 13.5 & 0.03 & $1970-89$ \\
\hline Mexico & 41.9 & 6.1 & 43.1 & 0.68 & $1970-89$ \\
\hline Nepal & 9.3 & 4.2 & 15.2 & 0.01 & $1970-89$ \\
\hline Netherlands & 5.0 & 3.6 & 7.9 & -0.19 & $1970-89$ \\
\hline Norway & 8.4 & 1.4 & 7.7 & -0.00 & $1970-89$ \\
\hline Pakistan & 9.5 & 7.2 & 14.9 & -0.03 & $1970-89$ \\
\hline Peru & 253.9 & 4.2 & 162.6 & 0.03 & $1970-89$ \\
\hline Philippines & 14.8 & 1.9 & 19.4 & -0.16 & $1970-89$ \\
\hline Singapore & 4.7 & -2.0 & 14.2 & 0.03 & $1970-89$ \\
\hline Spain & 12.3 & 3.6 & 20.2 & 0.00 & $1970-89$ \\
\hline Sweden & 8.3 & 3.2 & 11.0 & 0.40 & $1970-89$ \\
\hline Switzerland & 4.1 & 0.3 & 3.2 & 0.17 & $1970-89$ \\
\hline Thailand & 6.9 & 3.1 & 12.9 & -0.03 & $1970-89$ \\
\hline United Kingdom & 10.0 & 3.0 & 9.0 & 0.41 & $1970-89$ \\
\hline United States & 6.3 & 3.0 & 7.1 & 0.25 & $1970-89$ \\
\hline Uruguay & 58.4 & 2.6 & 55.7 & -0.13 & $1970-89$ \\
\hline Venezuela & 14.8 & 0.9 & 19.4 & 0.05 & $1970-89$ \\
\hline Yugoslavia & 104.0 & 0.4 & 170.2 & -0.04 & $1970-89$ \\
\hline Zambia & 24.8 & 12.3 & 28.8 & -0.01 & $1970-89$ \\
\hline Canada & 7.0 & 3.5 & 9.0 & 0.00 & $1970-88$ \\
\hline Ghana & 44.5 & 4.6 & 40.2 & 0.14 & $1970-88$ \\
\hline New Zealand & 12.0 & 4.9 & 11.7 & 0.09 & $1970-88$ \\
\hline Barbados & 10.7 & 3.7 & 14.8 & -0.00 & $1972-89$ \\
\hline Brazil & 85.1 & 3.2 & 108.8 & 0.76 & $1970-87$ \\
\hline Iceland & 37.1 & 3.0 & 40.1 & -0.01 & $1972-89$ \\
\hline Kenya & 12.3 & 5.2 & 16.2 & -0.00 & $1972-89$ \\
\hline Portugal & 18.7 & 8.6 & 23.3 & 0.17 & $1972-89$ \\
\hline Colombia & 21.4 & 1.6 & 28.8 & -0.01 & $1970-85$ \\
\hline Morocco & 7.7 & 7.7 & 13.9 & 0.27 & $1970-85$ \\
\hline Tanzania & 18.2 & 6.6 & 21.5 & 0.07 & $1970-85$ \\
\hline Argentina & 178.0 & 4.5 & 224.6 & 0.07 & $1970-84$ \\
\hline Bahamas & 6.1 & 2.5 & 10.3 & 0.01 & $1976-89$ \\
\hline
\end{tabular}


APPENDIX TABLE A1 continued

\begin{tabular}{|c|c|c|c|c|c|}
\hline Country & $\begin{array}{c}\text { Inflation } \\
(\%, \text { Annual Average })\end{array}$ & $\begin{array}{c}\text { Deficits } \\
\text { (\% of GDP, Average) }\end{array}$ & $\begin{array}{c}\text { Base Money Growth } \\
\text { (Average) }\end{array}$ & $\begin{array}{l}\text { Correlation between } \\
\text { Infl. and Deficits }\end{array}$ & Time Period \\
\hline Italy & 14.0 & 34.4 & 16.1 & 0.02 & $1970-83$ \\
\hline Nicaragua & 83.3 & 11.8 & 62.5 & 0.04 & $1973-86$ \\
\hline Botswana & 10.9 & -8.7 & 26.3 & 0.44 & $1977-89$ \\
\hline Turkey & 31.7 & 3.1 & 37.6 & 0.19 & $1970-81$ \\
\hline Zaire & 42.8 & 9.3 & 42.3 & 0.06 & $1971-82$ \\
\hline Malta & 3.6 & 1.6 & 3.4 & -0.19 & $1980-89$ \\
\hline Romania & 3.3 & -4.3 & 9.1 & 0.05 & $1980-89$ \\
\hline Zimbabwe & 21.8 & 6.7 & 23.3 & 0.14 & $1980-89$ \\
\hline & & & \multicolumn{2}{|c|}{ Cross-Section Averages } & Total Panel \\
\hline \multicolumn{3}{|c|}{ Correlation between inflation and deficits } & \multicolumn{2}{|c|}{0.02} & 0.005 \\
\hline \multicolumn{3}{|c|}{ Correlation between inflation and base money growth } & \multicolumn{2}{|c|}{0.85} & 0.58 \\
\hline \multicolumn{3}{|c|}{ Correlation between deficits and base money growth } & \multicolumn{2}{|c|}{0.01} & 0.01 \\
\hline
\end{tabular}

Note: The countries are first grouped based on the number of observations available in a descending order, and then within the group in an alphabetical order.

APPENDIX TABLE A2

Normalized, Inverted Averages of Institutional Indices

\begin{tabular}{|c|c|c|c|c|c|}
\hline Country & $\begin{array}{l}\text { Legal-CBI } \\
\text { (a) }\end{array}$ & $\begin{array}{c}\text { TOR } \\
\text { (b) }\end{array}$ & $\begin{array}{l}\text { Priv. CR in Total } \\
\text { (c) }\end{array}$ & $\begin{array}{l}\text { M2/GDP } \\
\text { (d) }\end{array}$ & $\begin{array}{c}\text { CIM } \\
\text { (e) }\end{array}$ \\
\hline Australia & 0.13 & 0.17 & 0.65 & 0.50 & 0.14 \\
\hline Austria & 0.60 & 0.17 & 0.65 & 0.77 & 0.09 \\
\hline Belgium & 0.95 & 0.17 & 0.80 & 0.73 & 0.46 \\
\hline Chile & 0.51 & 0.67 & 0.73 & 0.89 & 0.31 \\
\hline Costa Rica & 0.40 & 0.67 & 0.70 & 0.82 & 0.31 \\
\hline Germany & 0.00 & 0.11 & 0.59 & 0.64 & 0.13 \\
\hline Denmark & 0.35 & 0.01 & 0.53 & 0.70 & 0.04 \\
\hline Ethiopia & 0.52 & 0.26 & 0.88 & 0.92 & 1.00 \\
\hline Finland & 0.74 & 0.12 & 0.45 & 0.74 & 0.00 \\
\hline France & 0.79 & 0.23 & 0.55 & 0.44 & 0.11 \\
\hline Greece & 0.25 & 0.28 & 0.81 & 0.65 & 0.44 \\
\hline Honduras & 0.47 & 0.21 & 0.66 & 0.92 & 0.47 \\
\hline India & 0.63 & 0.41 & 0.76 & 0.83 & 0.58 \\
\hline Ireland & 0.46 & 0.18 & 0.67 & 0.73 & 0.25 \\
\hline Israel & 0.54 & 0.17 & 0.77 & 0.61 & 0.10 \\
\hline Japan & 0.92 & 0.23 & 0.56 & 0.34 & 0.09 \\
\hline Korea (South) & 0.72 & 0.39 & 0.52 & 0.84 & 0.24 \\
\hline Malaysia & 0.60 & 0.12 & 0.54 & 0.68 & 0.35 \\
\hline Mexico & 0.63 & 0.22 & 0.85 & 0.94 & 0.43 \\
\hline Nepal & 0.92 & 0.19 & 0.72 & 0.95 & 0.82 \\
\hline Netherlands & 0.49 & 0.06 & 0.60 & 0.53 & 0.13 \\
\hline Norway & 0.95 & 0.06 & 0.65 & 0.63 & 0.18 \\
\hline Pakistan & 0.87 & 0.30 & 0.75 & 0.77 & 0.72 \\
\hline Peru & 0.47 & 0.36 & 0.81 & 0.94 & 0.51 \\
\hline Philippines & 0.47 & 0.13 & 0.63 & 0.89 & 0.30 \\
\hline Singapore & 0.73 & 0.43 & 0.00 & 0.55 & 0.35 \\
\hline Spain & 0.96 & 0.18 & 0.62 & 0.45 & 0.15 \\
\hline Sweden & 0.73 & 0.21 & 0.69 & 0.65 & 0.16 \\
\hline
\end{tabular}


APPENDIX TABLE A2 continued

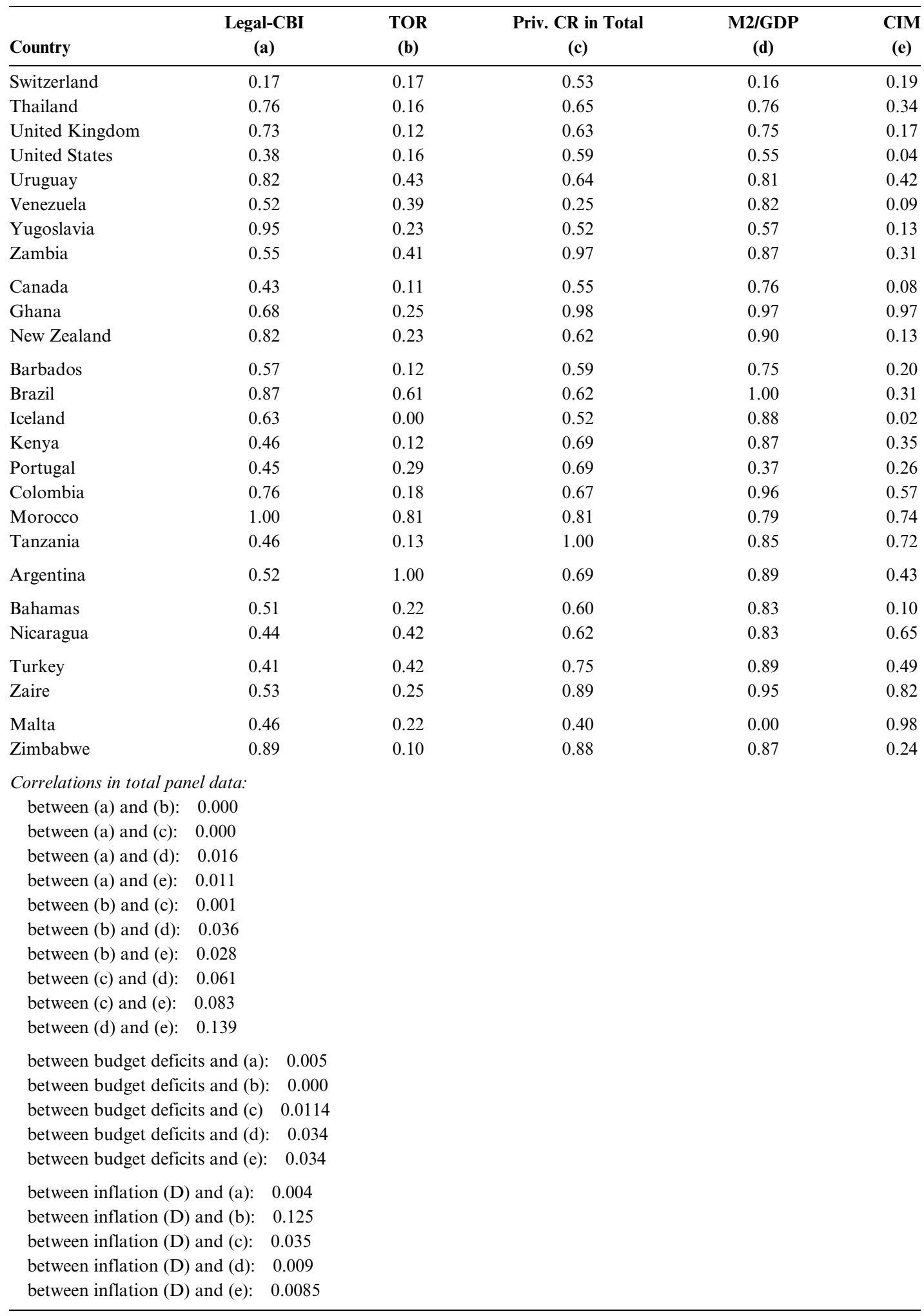

Notes: See note 13 for the procedure to normalize and invert the CBI and FMD indices. This table reports the averages of the resulting indices. Countries are ordered according to their time-series lengths reported in Appendix table A1. 


\title{
APPENDIX TABLE A3
}

\author{
Abbreviations and Sources of Data
}

\begin{tabular}{|c|c|}
\hline$D$ & $\begin{array}{l}\text { Real rate of depreciation in money balances } \\
\text { (inflation rate } /[1+\text { inflation rate]) (Source for the inflation rate: IMF-IFS) }\end{array}$ \\
\hline Def & Consolidated government deficits in percentage of GDP (source: IMF-IFS) \\
\hline$D e f C B I$ & Def, multiplied by inverted normalized index of legal-CBI \\
\hline DefTOR & Def, multiplied by the normalized index of $T O R$ \\
\hline Def PRCR & $\begin{array}{l}\text { Def, multiplied by the inverted and normalized index of the ratio of } \\
\text { private credit in total banking sector credit }\end{array}$ \\
\hline DefM2 & Def, multiplied by the inverted and normalized index of $M 2$ \\
\hline DefCIM & Def, multiplied by the inverted and normalized index of CIM \\
\hline$g G D P$ & Rate of growth of real GDP (Source: IMF-IFS) \\
\hline$g M$ & Rate of growth of base (reserve) money (source: IMF-IFS) \\
\hline IMF-IFS & International Financial Statistics of the International Monetary Fund \\
\hline lCBI & Lack of CBI (CBI on an inverted scale, see note 13) \\
\hline IFMD & Lack of FMD (FMD on an inverted scale, see note 13) \\
\hline legal-CBI & Index of CBI (Cukierman et al., 1992) \\
\hline$T O R$ & Turnover rate of central bank presidents \\
\hline
\end{tabular}

Note: See Section IIIA for further detail.

\section{REFERENCES}

Ahking, F. W., and S. Miller. "The Relationship between Government Deficits, Money Growth and Inflation." Journal of Macroeconomics, 7, 1986, 447-67.

Al-Marhubi F., and T. D. Willett. "The Anti-Inflationary Influence of Corporatist Structures and Central Bank Independence: The Importance of the HumpedShaped Hypothesis.” Public Choice, 84, 1995, 153-62.

Alesina, A., and L. Summers. "Central Bank Independence and Macroeconomic Performance: Some Comparative Evidence." Journal of Money, Credit and Banking, 25, 1993, 151-62.

Alesina, A., and G. Tabellini, "Rules versus Discretion with Non-coordinated Monetary and Fiscal Policies." Economic Inquiry, 25, 1987, 619-30.

Arellano, M., and S. Bond. "Dynamic Panel Data Estimation Using DPD.” Working Paper Series No. 88/15, Institute of Fiscal Studies, 1988.

Bailey, M. "The Welfare Cost of Inflationary Finance." Journal of Political Economy, 64, 1956, 93-114.

Balestra, P., and M. Nerlove. "Pooling Cross Section and Time Series Data in the Estimation of a Dynamic Model: The Demand for Natural Gas." Econometrica, 34, 1966, 585-612.

Banaian, K., R. C. K. Burdekin, and T. D. Willett. "Reconsidering the Principal Components of Central Bank Independence: The More the Merrier?" Public Choice, 97, 1998, 1-12.

Burdekin, R. C. K., and M. E. Wohar. "Monetary Institutions, Budget Deficits and Inflation." European Journal of Political Economy, 6, 1990, 531-51.

Cagan, P. Studies in the Quantity Theory of Money, edited by M. Friedman. Chicago: University of Chicago Press, 1956.

Choudhary, M. A. S., and A. K. Parai. "Budget Deficit and Inflation: The Peruvian Experience." Applied Economics, 23, 1991, 1117-21.
Clague, C., P. Keefer, S. Knack, and M. Olson. "ContractIntensive Money: Contract Enforcement, Property Rights and Economic Performance." Mimeo, Center for Institutional Reform and Informal Sector, University of Mayland, College Park, 1995.

Cukierman, A. Central Bank Strategy, Credibility and Independence: Theory and Evidence. Cambridge, MA: MIT Press, 1992.

Cukierman, A., B. Neyapti, and S. Webb. "Measuring the Independence of Central Banks and Its Effects on Policy Outcomes." World Bank Economic Review, 6, 1992, 353-98.

Cukierman, A., G. Miller, and B. Neyapti, "Central Bank Reform, Liberalization and Inflation in Transition Economies, an International Perspective.” Journal of Monetary Policy, 49, 2002, 237-64.

Darrat, A. F. "Inflation and Federal Budget Deficits: Some Empirical Results." Public Finance Quarterly, 13, 1985, 206-15.

Dwyer, G. P. Jr. "Inflation and Government Deficits." Economic Inquiry, 20, 1982, 315-29.

Easterly, W., C. A. Rodriguez, K. Schmidt-Hebbel (Eds.). Public Sector Deficits and Macroeconomic Performance. New York: Oxford University Press, 1994.

Ghani, E. "How Financial Markets Affect Long-Run Growth: A Cross-Country Study.” Policy Research Working Papers No. 843, World Bank, 1992.

Giannaros D. S., and B. R. Kolluri. "Deficit Spending, Money, and Inflation: Some International Empirical Evidence." Journal of Macroeconomics, 7, 1985, 401-17.

Goldsmith, R. W. Financial Structure and Development. New Haven, CT: Yale University Press, 1969.

Goodman, J. B. "The Politics of Central Bank Independence." Comparative Politics, April 1991, 329-49.

Grilli, V., D. Masciandaro, and G. Tabellini. "Institutions and Policies." Economic Policy, 6, 1991, 342-92. 
International Monetary Fund (IMF). International Financial Statistics. Washington, DC: International Monetary Fund, various issues.

King, R. G., and R. Levine. "Financial Indicators and Growth in a Cross-Section of Countries." Policy Research Working Papers No. 819, World Bank, 1992.

Maxfield, S. "Financial Incentives and Central Bank Authority in Industrializing Nations." World Politics, 46, 1994, 556-88.

Metin, K. "The Relationship between Inflation and Budget Deficits in Turkey." Journal of Business and Economic Statistics, 16, 1998, 412-22.

Neyapti, B. "Central Bank Independence and Economic Performance in Eastern Europe." Economic Systems, 25, 2001, 381-99.

Nickell, S. "Biases in Dynamic Models with Fixed Effects.” Econometrica, 49, 1981, 1417-26.

Parkin, M., and R. Bade. "Central Bank Laws and Monetary Policy: A Preliminary Investigation,” in M.G. Porter (Ed.) The Australian Monetary System in the 1970s, edited by M.G. Porter. Clayton, Australia: Monash University, 1978.

Posen, A. "Why Central Bank Independence Does Not Cause Low Inflation," in Finance and International Economy. New York: Oxford University Press, 1994.

"Declerations Are Not Enough: Financial Sector Sources of Central Bank Independence," in NBER Macroeconomic Annual 1995, edited by B. Bernanke and J.J. Rotemberg. Cambridge, MA: MIT Press, 1995, 255-95.

Rogoff, K. "The Optimal Degree of Commitment to an Intermediate Monetary Target." Quarterly Journal of Economics, 100, 1985, 1169-89.

Sargent, T. J. Rational Expectations and Inflation. New York: Harper \& Row, 1986.

Sargent, T. J., and N. Wallace. "Some Unpleasant Monetary Arithmetics." Federal Reserve Board of Minneapolis Quarterly Review, 9, 1985, 15-31.

Tanzi, V. "Inflation, Lags in Collection, and the Real Value of Tax Revenue.” IMF Staff Papers No. 24, 1977. 